Research Journal of Applied Sciences, Engineering and Technology 7(2): 403-412, 2014

DOI:10.19026/rjaset.7.268

ISSN: 2040-7459; e-ISSN: 2040-7467

(C) 2014 Maxwell Scientific Publication Corp.

\begin{tabular}{lll}
\hline Submitted: April 23, 2013 & Accepted: May 03, 2013 & Published: January 10, 2014
\end{tabular}

\title{
Research Article \\ Building the Method and the Mathematical Model to Determine the Rate of Freezing Water inside Royal Jelly in the Freezing Process
}

\author{
Nguyen Tan Dzung \\ Department of Food Technology, Faculty of Chemical and Food Technology, HCMC University of \\ Technical Education, 01-Vo Van Ngan Street, Thu Duc District, Viet Nam, Tel.: 0918801670
}

\begin{abstract}
The aim of this study is building the new method and the mathematical model to determine the rate of freezing water inside Royal jelly of the freezing process for using in preservation as well as for using in the freeze drying. The results obtained were used to determine the optimal freezing temperature of Royal jelly for preservation of $-5.73^{\circ} \mathrm{C}$ (corresponding to the rate of freezing water inside Royal jelly of $86.02 \%$ over $86 \%$ ) and for the freeze drying of $-18.33^{\circ} \mathrm{C}$ (corresponding to the rate of freezing water inside Royal jelly of $100 \%$ ). This is basic parameters and very essential to set up the technological mode of the freezing process Royal jelly for preservation as well as for freeze drying.
\end{abstract}

Keywords: Royal jelly, the freezing process, the freezing process of royal jelly, the mathematical model of determining rate of freezing water, the optimal freezing temperature of royal jelly, the rate of freezing water inside royal jelly, the royal jelly preservation

\section{INTRODUCTION}

The Royal jelly has been verified to be rich in essential nutrients. The chemical composition of Royal jelly contain many different substance but the principal constituents of Royal jelly are water, protein, sugars, lipids and mineral salts. Although they occur with notable variations the composition of Royal jelly remains relatively constant when comparing different colonies, bee races and time. This thing can be seen analytic data in Table 1 .

Protein of Royal jelly contains all amino acids essential for humans, including 29 amino acids and derivatives. The most important is still aspartic acid, glutamic acid and the free amino acids as proline and lysine. Besides, it also contains a number of enzymes including glucose oxidase phosphatase and cholinesterase and an insulin-like substance (Antinelli et al., 2003).

The sugars consist mostly of fructose and glucose in relatively constant proportions similar to those in honey. Fructose is prevalent. In many cases fructose and glucose together account for $90 \%$ of the total sugars. The sucrose content varies considerably from one sample to another. Other sugars present in much lower quantities are maltose, trehalose, melibiose, ribose and erlose (Lercker et al., 1992).

The lipid of Royal jelly contain biologically active substances rare. The lipid fraction consists to $80-90 \%$ (by dry weight) of free fatty acids with unusual and uncommon structures. They are mostly short chain (8 to 10 carbon atoms) hydroxy fatty acids or dicarboxylic

\begin{tabular}{lll}
\multicolumn{3}{l}{ Table 1: Composition of royal jelly (Lercker et al., 1984, 1992) } \\
\hline Substance & Minimum value & Maximum value \\
\hline Water & $57 \%$ & $70 \%$ \\
Proteins $(\mathrm{N} \times 6.25)$ & $17 \%$ of dry weight & $45 \%$ of dry weight \\
Carbohydrate (sugars) & $18 \%$ of dry weight & $52 \%$ of dry weight \\
Lipids & $3.5 \%$ of dry weight & $19 \%$ of dry weight \\
Minerals & $2 \%$ of dry weight & $3 \%$ of dry weight \\
\hline
\end{tabular}

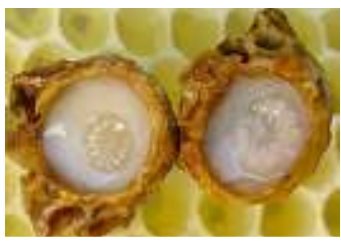

Fig. 1: The royal jelly

acids, in contrast to the fatty acids with 14 to 20 carbon atoms which are commonly found in animal and plant material. These fatty acids are responsible for most of the recorded biological properties of Royal jelly (Schmidt and Buchmann, 1992). The principal acid is 10-hydroxy -2-decenoic acid (10-hydroxydecenoic acid) and it can be called 10-HDA. In addition to the free fatty acids, the lipid fraction contains some neutral lipids, sterols (including cholesterol) and an unsaponifiable fraction of hydrocarbons similar to beeswax extracts (Lercker et al., 1984, 1992; Hattori et al., 2007) (Fig. 1).

The total ash content of Royal jelly is about $1 \%$ of fresh weight or 2 to $3 \%$ of dry weight. The major mineral salts are, in descending order: $\mathrm{K}, \mathrm{Ca}, \mathrm{Na}, \mathrm{Zn}$, $\mathrm{Fe}, \mathrm{Cu}$ and $\mathrm{Mn}$, with a strong prevalence of potassium (Benfenati et al., 1986). 
According to research of Schmidt and Buchmann (1992) showed that Royal jelly is extremely rich in vitamins to include water-soluble vitamins as $B_{1}$ (Thiamine), $\mathrm{B}_{2}$ (Riboflavin), $\mathrm{B}_{3}$ (Pantothenic acid), $\mathrm{B}_{6}$ (Pyridoxine), PP (Niacin), $B_{c}$ (Folic acid), H (Biotin) and fat-soluble vitamins as A (Retinol or Retinal), D (Calciumpherol), E (Tocopherol), K (Philoquinol).

It is obvious that the Royal jelly is kinds of pharmaceutical product, food to have a great value for human health. It has ability resistant to aging, increase energy and restore health to the body. For children it helps improve brain development. Therefore, the problem posed here is how to preserve the Royal jelly in order that they can be prolonged time of using and export but their quality is still contanst.

Currently, there are two methods the freezing and the freeze drying to apply for preservation the Royal jelly to achieve high effect. Therefore the problem of determining the technological mode of the freezing process for using preservation as well as for using freeze drying is extremely important. It solve problem about quality and expenses energy of final product. And one of basic parameters for determining the technological mode of the freezing process is the rate of freezing water of Royal jelly (Dzung, 2012). However, the problem of determining the rate of freezing water according to the freezing temperature of Royal jelly, simultaneously building the mathematical model about relationship between the rate of freezing water and the freezing temperature of Royal jelly are extremely complicated question.

According to overview of Bon and Tho (2002), there were many research on mathematical modeling about the rate of freezing water of flat-shaped cattle meat (Plank, 1913), frozen velocity of water inside flatshaped fish fillet (Shijov, 1931), rate of freezing water in wet materials (Raoult, 1958; Sbijov, 1967; Golovkin, 1972; Luikov, 1974; Heldman and Daryl, 1992). However, mathematical model of these authors was not suitable for determining rate of freezing water in Royal jelly because experimental results showed that error between the mathematical model and experimental data was higher than $24.36 \%$. Because of water in Royal jelly always contents dissolving compounds. Therefore, crystallization temperature, latent heat of freezing of water and other thermo physical parameters constantly change during the freezing process (Cleland and Earle, 1979; Heist, 1979; Holman, 1986; Gebhart, 1992). These are the main causes of error between the mathematical models with experimental data. In case of large error, it will not allow the use of mathematical modeling to determine the technological mode, (Heldman, 1982; Bon and Tho, 2002; Figura and Arthur, 2007).

As a result, the aim of this study was building a new method to determine the rate of freezing water according to the freezing temperature of Royal jelly, to set up the mathematical model about the relationship between the rate of freezing water and the freezing temperature of Royal jelly. On that foundation allow to determine the optimal freezing temperature of Royal jelly in freezing process (Dzung, 2012; Dzung et al., 2012b).

\section{BUILDING THE METHOD TO DETERMINE THE RATE OF FREEZING WATER}

The freezing process of royal jelly: From Fig. 2 can see that the freezing process of Royal jellies include stages (Dzung, 2007; Dzung et al., 2012):

- Cooling stage (AB): Reduce temperature of Royal jelly from the initial temperature $T_{R}$ (Room temperature of $25^{\circ} \mathrm{C}$ ) to the freezing temperature of water inside Royal jelly $\mathrm{T}_{\mathrm{cr}}=\mathrm{T}_{\mathrm{Fp}}=-1.06^{\circ} \mathrm{C}$ before freezing the Royal jelly, (Heldman and Daryl, 1992; Dzung et al., 2012).

- Extreme cold stage (BC): This stage occur in very short time when the temperature of Royal jelly is reduced under the freezing point of water in Royal jelly of $\mathrm{T}_{\mathrm{cr}}=\mathrm{T}_{\mathrm{Fp}}=-1.06^{\circ} \mathrm{C}$ but water in Royal jelly is still no crystallization.

- Freezing stage (CD): Water inside the Royal jelly was crystallized in environment to has temperatures of $T_{e}=-45^{\circ} \mathrm{C}$. This stage finished when the water inside the Royal jelly crystallized $86 \%$ for preservation or $100 \%$ for freeze drying. And temperature at value of this rate of freezing water is called the optimal freezing temperature of Royal jelly $\left(\mathrm{T}_{\mathrm{Fopt}},{ }^{\circ} \mathrm{C}\right)$, (Heldman and Daryl, 1992; Dzung, 2012; Dzung et al., 2012).

- Energy balance stage (DE): If freezing process is continued, this stage will be super freezing stage. It will be reducing the temperature of Royal jelly from $\mathrm{T}_{\mathrm{Fopt}}\left({ }^{\circ} \mathrm{C}\right)$ to the final temperature $\mathrm{T}_{\mathrm{e}}\left({ }^{\circ} \mathrm{C}\right)$ with $\mathrm{T}_{\mathrm{e}} \leq \mathrm{T}_{\mathrm{Fopt}}$, (Heldman and Daryl, 1992; Dzung, 2012; Dzung et al., 2012).

The thawing process of freezing royal jelly: From Fig. 2 can see that the thawing process will be carried out from E to A (Dzung, 2012; Dzung et al., 2012):

- Stage ED: This stage warm up freezing Royal jelly to vary the freezing temperature of Royal jelly from $T_{e}$ to $T_{F o p t}$ but not make to thaw ice inside freezing Royal jelly.

- Stage DB: This stage make to thaw ice inside freezing Royal jelly. At point B, ice inside Royal jelly is completely thawed, the temperature of Royal jelly reach the crystallization temperature.

- Stage BA: This stage warm up Royal jelly after ice completely thawing, the temperature of Royal jelly increase from $T_{\text {cr }}$ to $T_{R}$. 


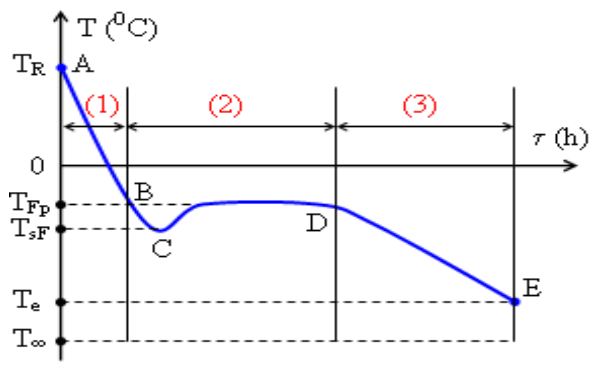

Fig. 2: The freezing process of royal jelly

AB: Cooling stage; BC: Extreme cold stage; CD: Crystalline water inside royal jelly stage; DE: Super freezing stage

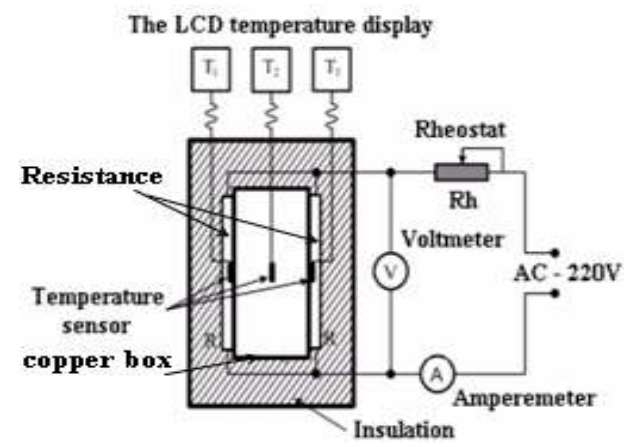

Fig. 3: Principle diagram of the equipment determine the rate of freezing water of moist material

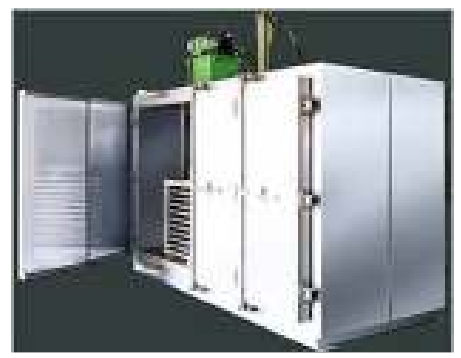

Fig. 4: The system of freeze DL-4, the temperature freezing environment $(-50 \div-45){ }^{\circ} \mathrm{C}$

It is obvious that Royal jelly is frozen to reach temperature of $T_{e}$ (Fig. 2). At value of this temperature, it is supplied heat to carry out the warming up and thawing process. From the balance energy equation of the warming up and thawing process of freezing Royal jelly will build the method to determine the rate of water freezing inside Royal jelly and the mathematical model about the relationship between the rate of freezing water and freezing temperature of Royal jelly.

Building the method to determine rate of freezing water of royal jelly: This is a new method to determine the rate of freezing water according to freezing temperature of Royal jelly, it was built on base the energy balance equation in the warming up and thawing process of Royal jelly after being frozen by the experimental method. The results obtained could be applied to determine the optimal freezing temperature of Royal jelly of the freezing process $\left(\mathrm{T}=\mathrm{T}_{\mathrm{Fopt}}\right)$.

According to overview of Dzung (2007), if freezing Royal jelly use in preservation, the optimal freezing temperature will reach value of $\mathrm{T}_{\mathrm{Fopt}}$, corresponding to the rate of freezing water over $86 \%$. Iffreezing Royal jelly use in freeze drying, the optimal freezing temperature will reach value of $\mathrm{T}_{\mathrm{Fopt}}$, corresponding to the rate of freezing water of $100 \%$, (Dzung, 2012; Dzung et al., 2012).

The rate of freezing water $(\omega, 0 \leq \omega \leq 1)$ of Royal jelly was defined as follow, (Heist, 1979):

$$
\omega=\frac{\mathrm{G}_{\mathrm{db}}}{\mathrm{G}_{\mathrm{n}}}
$$

where, $G_{\mathrm{db}}, \mathrm{G}_{\mathrm{n}}(\mathrm{kg})$-amount of crystallized water and total water of Royal jelly. The rate of freezing water $\omega$ was determined by equipment in Fig. 3 .

Determine the loss of heat coefficient of equipment: Water was poured into the copper box of equipment in Fig. 3. All of them were put in the system of freeze DL4 (Fig. 4). The freezing process is carried out until the temperature of water in the copper box reached $-45^{\circ} \mathrm{C}$, water was completely crystallized. Following, the copper box was taken out the system of freeze DL-4, the insulated lid of copper box and equipment in Fig. 3 must be closed. Next this stage, the warming up and thawing process were carried out to determine the loss of heat pass the heat-insulated surrounding area of equipment in Fig. 3 (Dzung et al., 2012).

The heat was supplied for equipment in Fig. 3 (Electrical calorimeters) by the electric resistance: $\mathrm{Q}=$ $\mathrm{UI} \tau(\mathrm{J})$. It was divided into three parts as follows (Jean et al., 1996):

$$
\mathrm{Q}=\mathrm{Q}_{\mathrm{s}}+\mathrm{Q}_{\mathrm{cu}}+\mathrm{Q}_{\mathrm{dn}}
$$

where,

$\mathrm{Q}_{\mathrm{s}}(\mathrm{J})=$ The loss of heat pass the heat-insulated surrounding area of equipment in Fig. 3

$\mathrm{Q}_{\mathrm{cu}}(\mathrm{J})=$ The heat warm up the copper box of equipment in Fig. 3 from $T_{d}$ to $T_{c}$ and to be determined as follows:

$$
\mathrm{Q}_{\mathrm{cu}}=\mathrm{G}_{1} \mathrm{c}_{1}\left(\mathrm{~T}_{\mathrm{c}}-\mathrm{T}_{\mathrm{d}}\right),(\mathrm{J})
$$

$\mathrm{Q}_{\mathrm{dn}}(\mathrm{J})=$ The heat warm up ice inside the copper box of equipment in Fig. 3 from $T_{d}$ to $T_{c}$ and to be determined as follows:

$\mathrm{Q}_{\mathrm{dn}}=\mathrm{Gc}\left(\mathrm{T}_{\mathrm{c}}-\mathrm{T}_{\mathrm{d}}\right),(\mathrm{J})$

From Eq. (2) can write as follows: 
Res. J. Appl. Sci. Eng. Technol., 7(2): 403-412, 2014

Table 2: The experimental data to determine the loss of heat coefficient of equipment

\begin{tabular}{lllllll}
\hline $\mathrm{U}(\mathrm{V})$ & $\mathrm{I}(\mathrm{A})$ & $\tau(\mathrm{s})$ & $\mathrm{T}_{\mathrm{d}}\left({ }^{\circ} \mathrm{C}\right)$ & $\mathrm{T}_{\mathrm{c}}\left({ }^{\circ} \mathrm{C}\right)$ & $\mathrm{c}(\mathrm{J} /(\mathrm{kg} . \mathrm{K})$ & $\varphi$ \\
\hline 110 & 0.25 & 54.39 & 43.53 & 45.39 & 4173.98 & 0.1312 \\
110 & 0.25 & 52.24 & 14.63 & 16.42 & 4167.11 & 0.1309 \\
110 & 0.25 & 54.09 & -1.72 & 1.78 & 2062.48 & 0.1311 \\
110 & 0.25 & 54.74 & -16.29 & -12.61 & 1974.49 & 0.1309 \\
110 & 0.25 & 55.34 & -41.06 & -37.08 & 1824.88 & 0.1312 \\
\hline
\end{tabular}

$$
\begin{aligned}
& Q_{s}=Q-\left(Q_{c u}+Q_{d n}\right) \\
& \varphi=\frac{Q_{s}}{Q}=1-\frac{\left(G_{1} c_{1}+G c\right)}{U I \tau}\left(T_{c}-T_{d}\right)
\end{aligned}
$$

where,

$\varphi \quad$ : The loss of heat coefficient of equipment Fig. 3

$\mathrm{G}_{\mathrm{n}}=\mathrm{G}=0.156 \mathrm{~kg}$ : Weight of water in copper box

$\mathrm{c}=\mathrm{c}_{\mathrm{n}}$ or $\mathrm{c}=\mathrm{c}_{\mathrm{nd}}$ : Specific heat of water or ice

$\mathrm{T}=\left(\mathrm{T}_{\mathrm{d}}+\mathrm{T}_{\mathrm{c}}\right) / 2$ : The average temperature of the samples

$\mathrm{T}_{\mathrm{d}}\left({ }^{\circ} \mathrm{C}\right)$ : Temperature of the samples before warming up and heat balance

$\mathrm{T}_{\mathrm{c}}\left({ }^{\circ} \mathrm{C}\right)$ : Temperature of the samples after warming up and heat balance

$\mathrm{U}(\mathrm{V}) \quad$ : Number of Voltmeter

I (A) : Number of Amperemeter

$\tau(\mathrm{s}) \quad$ : Time of the warming up process

Right here, the conditions of $\mathrm{U}=110 \mathrm{~V}$ and $\mathrm{I}=$ $0.25 \mathrm{~A}$ were constant, carrying out experiment at different value of time obtained experimental data in Table 2.

Using Eq. (5) to determine the loss of heat coefficient of equipment in Fig. 3, it can see results after calculating in Table 2 . The average loss of heat coefficient determined $\varphi=0.1311$ (Dzung et al., 2012).

Building the mathematical model to determine rate of freezing water of royal jelly by experiment: The Royal jelly was also poured into the copper box of equipment in Fig. 3. All of them were put in the system of freeze DL-4. The freezing process was carried out until the temperature of Royal jelly in the copper box reached $-30^{\circ} \mathrm{C}$; water in Royal jelly was completely crystallized. Following, the copper box was taken out the system of DL-4, the insulated lid of copper box and equipment in Fig. 3 must be closed. Next this stage, the warming up and thawing process were carried out to determine the rate of freezing water according to freezing temperature of Royal jelly (Dzung, 2012; Dzung et al., 2012).

From Eq. (2) can write as follows:

$$
\begin{aligned}
& \mathrm{Q}_{\mathrm{dn}}=\mathrm{Q}-\mathrm{Q}_{\mathrm{s}}-\mathrm{Q}_{\mathrm{dn}}=(1-\varphi) \mathrm{Q}-\mathrm{Q}_{\mathrm{cu}}=(1-\varphi) \mathrm{UI} \tau- \\
& \mathrm{G}_{1} \mathrm{c}_{1}\left(\mathrm{~T}_{\mathrm{c}}-\mathrm{T}_{\mathrm{d}}\right),(\mathrm{J})
\end{aligned}
$$

The heat warm up freezing Royal jelly to vary temperature from $T_{d}$ to $T_{c}$. This heat was divided into four parts as follows: where,

$$
\mathrm{Q}_{\mathrm{dn}}=\mathrm{Gc}\left(\mathrm{T}_{\mathrm{c}}-\mathrm{T}_{\mathrm{d}}\right)=\mathrm{Q}_{1}+\mathrm{Q}_{2}+\mathrm{Q}_{3}+\mathrm{Q}_{4},(\mathrm{~J})
$$

$\mathrm{Q}_{1}(\mathrm{~J})$ : The heat warm up to thaw a part of ice (crystallized water) inside the Royal jelly:

$$
\mathrm{Q}_{1}=\mathrm{LW}_{\mathrm{a}}(1-\omega) \mathrm{G},(\mathrm{J})
$$

$\mathrm{Q}_{2}(\mathrm{~J})$ : The heat warm up to vary temperature of ice inside the Royal jelly form $T_{d}$ to $T_{c}$ :

$$
\mathrm{Q}_{2}=\mathrm{c}_{\mathrm{nd}} \mathrm{GW}_{\mathrm{a}} \omega\left(\mathrm{T}_{\mathrm{c}}-\mathrm{T}_{\mathrm{d}}\right),(\mathrm{J})
$$

$\mathrm{Q}_{3}(\mathrm{~J})$ : The heat warm up to vary temperature of water after ice thawing inside the Royal jelly form $T_{d}$ to $\mathrm{T}_{\mathrm{c}}$ :

$$
\mathrm{Q}_{3}=\mathrm{c}_{\mathrm{n}} \mathrm{G} \mathrm{W}_{\mathrm{a}}(1-\omega)\left(\mathrm{T}_{\mathrm{c}}-\mathrm{T}_{\mathrm{d}}\right),(\mathrm{J})
$$

$\mathrm{Q}_{4}(\mathrm{~J})$ : The heat warm up to temperature of the dry weight inside the Royal jelly form $T_{d}$ to $T_{c}$ :

$$
\mathrm{Q}_{4}=\mathrm{c}_{\mathrm{ck}} \mathrm{G}\left(1-\mathrm{W}_{\mathrm{a}}\right)\left(\mathrm{T}_{\mathrm{c}}-\mathrm{T}_{\mathrm{d}}\right),(\mathrm{J})
$$

Note: $T=\left(T_{d}+T_{c}\right) / 2$-the average temperature of the Royal jelly samples.

If $\mathrm{T}>\mathrm{T}_{\text {cr }}=-1.06^{\circ} \mathrm{C}$ :

$$
\omega=0, Q_{1}=0, Q_{2}=0, Q_{3} \neq 0, Q_{4} \neq 0
$$

If $-1.06^{0} \mathrm{C}=\mathrm{T}_{\mathrm{cr}} \leq \mathrm{T} \leq \mathrm{T}_{\mathrm{Fopt}}$ :

$0 \leq \omega \leq 1, \mathrm{Q}_{1} \neq 0, \mathrm{Q}_{2} \neq 0, \mathrm{Q}_{3} \neq 0, \mathrm{Q}_{4} \neq 0$

If $\mathrm{T}<\mathrm{T}_{\text {Fopt }}$ :

$$
\omega=1, \mathrm{Q}_{1}=0, \mathrm{Q}_{3}=0, \mathrm{Q}_{2} \neq 0, \mathrm{Q}_{4} \neq 0
$$

Substituting Eq. (6), (8), (9), (10) and (11) into Eq. (7). And it was written as follows:

$$
\begin{aligned}
& (1-\varphi) U I \tau-G_{1} c_{1}\left(T_{c}-T_{d}\right)=L_{a}(1-\omega) G+c_{n d} \\
& G_{a} \omega\left(T_{c}-T_{d}\right)+c_{n} G W_{a}(1-\omega)\left(T_{c}-T_{d}\right)+c_{c k} G(1 \\
& \left.-W_{a}\right)\left(T_{c}-T_{d}\right)
\end{aligned}
$$

This equation can be written by Eq. (12):

$$
\begin{aligned}
\omega & =\frac{(1-\varphi) U I \tau-L_{a} G}{\left(\left(c_{n d}-c_{n}\right)\left(T_{c}-T_{d}\right)-L\right) W_{a} G} \\
& -\frac{\left[G\left(c_{n} W_{a}+c_{c k}\left(1-W_{a}\right)\right)+c_{1} G_{1}\right]\left(T_{c}-T_{d}\right)}{\left(\left(c_{n d}-c_{n}\right)\left(T_{c}-T_{d}\right)-L\right) W_{a} G}
\end{aligned}
$$

where,

$\phi_{1}=\mathrm{LW}_{\mathrm{a}} \mathrm{G}$

$\phi_{2}=\left(\mathrm{c}_{\mathrm{n}} \mathrm{W}_{\mathrm{a}}+\mathrm{c}_{\mathrm{ck}}\left(1-\mathrm{W}_{\mathrm{a}}\right)\right) \mathrm{G}+\mathrm{c}_{1} \mathrm{G}_{1}$

$\phi_{3}=\mathrm{GW}_{\mathrm{a}}\left(\mathrm{c}_{\mathrm{nd}}-\mathrm{c}_{\mathrm{n}}\right)$ 
Res. J. Appl. Sci. Eng. Technol., 7(2): 403-412, 2014

Therefore, the rate of freezing water inside Royal jelly was determined by Eq. (13):

$$
\omega=\frac{(1-\varphi) U I \tau-\phi_{1}-\phi_{2}\left(T_{c}-T_{d}\right)}{\phi_{3}\left(T_{c}-T_{d}\right)-\phi_{1}}
$$

where,

$c_{1}, G_{1}$ : Specific heat and weight of copper box of equipment in Fig. 3

$\mathrm{G} \quad$ : Weight of Royal jelly sample

$\mathrm{T}_{\mathrm{d}}=\mathrm{T}_{1}=\mathrm{T}_{2}=\mathrm{T}_{3}$ : Initial temperature of Royal jelly sample before supplying energy

$\mathrm{T}_{\mathrm{c}}=\mathrm{T}_{1}{ }^{\prime}=\mathrm{T}_{2}{ }^{\prime}=\mathrm{T}_{3}{ }^{\prime}$ : Temperature of Royal jelly sample after supplying energy

U : Number of voltmeter

I : Number of amperermeter

$\tau \quad:$ Time of energy supply process

This much, the Eq. (13) is the mathematical model to determine the rate of freezing water according to freezing temperature of Royal jelly by the equipment and experiment.

Building the mathematical model about the relationship between the rate of freezing water and freezing temperature of royal jelly: According to overview of Bon and Tho (2002), the relationship the rate of freezing water and freezing temperature of moist material obey law the mathematical model of Sbijov (1967) as well as the mathematical model of Heldman and Daryl (1992) as follows:

$$
\omega(T)=b_{0}+b_{1} \exp \left(b_{2}+b_{3} T+b_{4} T^{2}\right)
$$

where, $\mathrm{T}\left({ }^{\circ} \mathrm{C}\right)$ is the average temperature of the freezing material samples; $b_{0}, b_{1}, b_{2}, b_{3}, b_{4}$ are parameters of the mathematical model (14); they are determined by the experimental data. This much, carrying out experiment and calculating according to Eq. (13) will obtain data of the rate of freezing water according to freezing temperature. Substituting this data into the Eq. (14) will determine parameters $b_{0}, b_{1}, b_{2}, b_{3}, b_{4}$.

\section{MATERIALS AND METHODS}

Materials: The Royal jelly is very thick solution and is grown in the Bao Loc area, Lam Dong province of Vietnam. The basic composition of Royal jelly is presented in Table 1 (Lercker et al., 1984, 1992).

Apparatus: Equipments used to determine rate of freezing water of Royal jelly are listed (Dzung et al., 2012):

- Determining weigh of royal jelly by satoriusbasic type BA310S: Range scale $(0 \div 350)$ g, error: $\pm 0.1 \mathrm{~g}= \pm 0.0001 \mathrm{~kg}$
Table 3: The experimental and calculating data to determine value of $\mathrm{U}, \mathrm{I}, \tau, \mathrm{T}_{\mathrm{d}}, \mathrm{T}_{\mathrm{c}}$, of royal jelly

\begin{tabular}{llllll}
\hline $\mathrm{U}(\mathrm{V})$ & $\mathrm{I}(\mathrm{A})$ & $\tau(\mathrm{s})$ & $\mathrm{T}_{\mathrm{d}}\left({ }^{\circ} \mathrm{C}\right)$ & $\mathrm{T}_{\mathrm{c}}\left({ }^{\circ} \mathrm{C}\right)$ & $\mathrm{c}_{\mathrm{n}}(\mathrm{J} /(\mathrm{kg} . \mathrm{K}))$ \\
\hline 110 & 2.50 & 131.51 & -0.20 & 0.20 & 4080.70 \\
110 & 2.50 & 100.16 & -1.98 & -0.20 & 4085.40 \\
110 & 2.50 & 58.66 & -3.18 & -1.98 & 4091.82 \\
110 & 2.50 & 40.99 & -4.08 & -3.18 & 4096.35 \\
110 & 2.50 & 27.29 & -5.28 & -4.08 & 4100.88 \\
110 & 2.50 & 19.66 & -6.18 & -5.28 & 4105.40 \\
110 & 2.50 & 10.46 & -7.38 & -6.18 & 4109.93 \\
60 & 2.50 & 14.06 & -8.28 & -7.38 & 4114.46 \\
60 & 0.25 & 83.10 & -9.48 & -8.28 & 4118.98 \\
60 & 0.25 & 68.53 & -10.38 & -9.48 & 4123.51 \\
60 & 0.25 & 47.52 & -11.58 & -10.38 & 4128.04 \\
60 & 0.25 & 31.59 & -12.48 & -11.58 & 4132.56 \\
60 & 0.25 & 33.63 & -13.56 & -12.48 & 4136.83 \\
60 & 0.25 & 33.17 & -14.68 & -13.56 & 4141.57 \\
60 & 0.25 & 29.37 & -15.74 & -14.68 & 4146.27 \\
60 & 0.25 & 26.27 & -16.72 & -15.74 & 4150.67 \\
60 & 0.25 & 28.34 & -17.80 & -16.72 & 4155.11 \\
60 & 0.25 & 27.52 & -18.86 & -17.80 & 4159.72 \\
60 & 0.25 & 25.91 & -19.86 & -18.86 & 4164.16 \\
60 & 0.25 & 27.41 & -20.92 & -19.86 & 4168.60 \\
60 & 0.25 & 28.90 & -22.04 & -20.92 & 4173.30 \\
60 & 0.25 & 21.12 & -22.86 & -22.04 & 4177.48 \\
60 & 0.25 & 34.95 & -24.22 & -22.86 & 4182.18 \\
60 & 0.25 & 21.03 & -25.04 & -24.22 & 4186.88 \\
\hline
\end{tabular}

Table 4: The experimental and calculating data to determine value of $c_{n d}, c_{c k}, L, \phi_{1}, \phi_{2 c}$, of royal jelly

\begin{tabular}{lllll}
\hline $\mathrm{c}_{\mathrm{nd}}(\mathrm{J} /(\mathrm{kg} \cdot \mathrm{K}))$ & $\mathrm{c}_{\mathrm{ck}}(\mathrm{J} /(\mathrm{kg} . \mathrm{K}))$ & $\mathrm{L}=\mathrm{r}_{\mathrm{nc}}(\mathrm{J} / \mathrm{kg})$ & $\phi_{1}$ & $\phi_{2}$ \\
\hline 2062.30 & 1705.85 & 333601.50 & 31203.75 & 539.16 \\
2055.68 & 1704.35 & 333600.35 & 31203.64 & 539.50 \\
2046.62 & 1702.30 & 333598.78 & 31203.50 & 539.97 \\
2040.24 & 1700.87 & 333597.67 & 31203.39 & 540.30 \\
2033.86 & 1699.44 & 333596.57 & 31203.29 & 540.63 \\
2027.48 & 1698.02 & 333595.46 & 31203.18 & 540.96 \\
2021.10 & 1696.61 & 333594.35 & 31203.08 & 541.30 \\
2014.72 & 1695.21 & 333593.25 & 31202.98 & 541.63 \\
2008.34 & 1693.81 & 333592.14 & 31202.87 & 541.96 \\
2001.96 & 1692.42 & 333591.03 & 31202.77 & 542.30 \\
1995.58 & 1691.03 & 333589.92 & 31202.67 & 542.63 \\
1989.19 & 1689.66 & 333588.82 & 31202.56 & 542.97 \\
1983.18 & 1688.37 & 333587.77 & 31202.47 & 543.28 \\
1976.49 & 1686.94 & 333586.61 & 31202.36 & 543.63 \\
1969.87 & 1685.54 & 333585.46 & 31202.25 & 543.98 \\
1963.67 & 1684.23 & 333584.39 & 31202.15 & 544.31 \\
1957.41 & 1682.91 & 333583.30 & 31202.05 & 544.64 \\
1950.91 & 1681.55 & 333582.17 & 31201.94 & 544.98 \\
1944.65 & 1680.25 & 333581.09 & 31201.84 & 545.31 \\
1938.39 & 1678.96 & 333580.00 & 31201.74 & 545.65 \\
1931.77 & 1677.60 & 333578.85 & 31201.63 & 546.00 \\
1925.87 & 1676.39 & 333577.83 & 31201.54 & 546.31 \\
1919.25 & 1675.05 & 333576.68 & 31201.43 & 546.66 \\
1912.63 & 1673.71 & 333575.53 & 31201.32 & 547.02 \\
\hline
\end{tabular}

- Determining temperature of royal jelly dual digital thermometer: range scale $(-50 \div 70){ }^{\circ} \mathrm{C}$, error $\pm 0.05^{\circ} \mathrm{C}$

- DL-4 Freezing System (Fig. 4) could reduce the temperature of environment to $(-50 \div-45){ }^{\circ} \mathrm{C}$. The temperature profile is measured by the automatic control system PLC

- Equipment used to identify the rate of freezing water of Royal jelly was shown in Fig. 3. The equipment includes a Voltmeter (range scale: $(0 \div 110) \mathrm{V}$, error: $\pm 1 \mathrm{~V}$ ), an amperemeter (range 
Res. J. Appl. Sci. Eng. Technol., 7(2): 403-412, 2014

Table 5: The experimental and calculating data to determine value of $\phi_{3}, \mathrm{~T}, \omega_{\mathrm{E}}$,

\begin{tabular}{llllll}
\multicolumn{7}{c}{$\omega_{\mathrm{MH}}$, error of royal jelly } \\
\hline$\phi_{3}$ & $\mathrm{~T}\left({ }^{\circ} \mathrm{C}\right)$ & $\omega_{\mathrm{E}}(\mathrm{T})$ & $\omega_{\mathrm{M}}(\mathrm{T})$ & Error $(\%)$ & $\left(\omega_{\mathrm{M}}-\omega_{\mathrm{E}}\right)^{2}$ \\
\hline-188.79 & 0.00 & 0.0000 & 0.0000 & - & $2.46596 \mathrm{E}-14$ \\
-189.85 & -1.09 & 0.2609 & 0.2718 & 4.16 & 0.000117847 \\
-191.30 & -2.58 & 0.5674 & 0.5554 & 2.11 & 0.000142878 \\
-192.32 & -3.63 & 0.6978 & 0.6989 & 0.15 & $1.12297 \mathrm{E}-06$ \\
-193.34 & -4.68 & 0.8058 & 0.8029 & 0.36 & $8.31163 \mathrm{E}-06$ \\
-194.36 & -5.73 & 0.8602 & 0.8754 & 1.77 & 0.000230635 \\
-195.38 & -6.78 & 0.9337 & 0.9239 & 1.05 & $9.6488 \mathrm{E}-05$ \\
-196.40 & -7.83 & 0.9515 & 0.9551 & 0.38 & $1.27715 \mathrm{E}-05$ \\
-197.42 & -8.88 & 0.9787 & 0.9744 & 0.44 & $1.86328 \mathrm{E}-05$ \\
-198.44 & -9.93 & 0.9814 & 0.9859 & 0.46 & $2.01456 \mathrm{E}-05$ \\
-199.46 & -10.98 & 0.9934 & 0.9925 & 0.09 & $8.28968 \mathrm{E}-07$ \\
-200.48 & -12.03 & 0.9967 & 0.9961 & 0.06 & $3.15655 \mathrm{E}-07$ \\
-201.44 & -13.02 & 0.9978 & 0.9980 & 0.02 & $4.05735 \mathrm{E}-08$ \\
-202.51 & -14.12 & 0.9984 & 0.9991 & 0.07 & $4.52419 \mathrm{E}-07$ \\
-203.57 & -15.21 & 0.9993 & 0.9996 & 0.03 & $7.98232 \mathrm{E}-08$ \\
-204.56 & -16.23 & 0.9997 & 0.9998 & 0.01 & $1.18221 \mathrm{E}-08$ \\
-205.56 & -17.26 & 0.9999 & 0.9999 & 0.00 & $2.51455 \mathrm{E}-10$ \\
-206.60 & -18.33 & 1.0000 & 1.0000 & 0.00 & $1.19831 \mathrm{E}-09$ \\
-207.60 & -19.36 & 1.0000 & 1.0000 & 0.00 & $2.02576 \mathrm{E}-10$ \\
-208.60 & -20.39 & 1.0000 & 1.0000 & 0.00 & $3.20484 \mathrm{E}-11$ \\
-209.66 & -21.48 & 1.0000 & 1.0000 & 0.00 & $4.23653 \mathrm{E}-12$ \\
-210.61 & -22.45 & 1.0000 & 1.0000 & 0.00 & $6.57414 \mathrm{E}-13$ \\
-211.67 & -23.54 & 1.0000 & 1.0000 & 0.00 & $7.55243 \mathrm{E}-14$ \\
-212.72 & -24.63 & 1.0000 & 1.0000 & 0.00 & $8.05528 \mathrm{E}-15$ \\
\hline & & & & &
\end{tabular}

scale: $(0 \div 2) \mathrm{A}$, error: $\pm 10 \mathrm{~mA})$ and an automatic timer (error: $\pm 0.001 \mathrm{~s}$ ). The Voltmeter is used to measure the potential difference of Resistance (R). The Amperemeter is used to determine the current intensity which passes through 2 resistances (R)

Methods: To determine the rate of freezing water by the experiment was carried out through 6 steps as follow, (Dzung, 2012; Dzung et al., 2012):

Step 1: Mass of the Royal jelly sample was weighed G $(\mathrm{kg})$ and put in the copper box of equipment in Fig. 3, it was frozen by the system of freeze DL-4 (Fig. 4) until the average temperature of the samples reached $-30^{\circ} \mathrm{C}$, water in Royal jelly was completely crystallized

Step 2: This copper box was taken out the system of freeze DL-4, the insulated lid of copper box and equipment in Fig. 3 must be closed. Untill energy balance of sample, the initial temperature of Royal jelly sample determined $\mathrm{T}_{\mathrm{d}}=\mathrm{T}_{1}=\mathrm{T}_{2}=\mathrm{T}_{3},\left({ }^{\circ} \mathrm{C}\right)$. Next this stage, the sample was supplied with energy from the electric resistance. Simultaneously, parameters such as U (V), I (A) and energy supply time $\tau$ (s) were determined. Subsequently, the system stopped supplying energy. The temperature of Royal jelly samples increased from $\left(\mathrm{T}_{1}, \mathrm{~T}_{2}, \mathrm{~T}_{3}\right)$ to $\left(\mathrm{T}_{1}{ }^{\prime}, \mathrm{T}_{2}, \mathrm{~T}_{3}{ }^{\prime}\right)$. When energy balance occurred, $\mathrm{T}_{\mathrm{c}}=\mathrm{T}_{1}{ }^{\prime}=\mathrm{T}_{2}{ }^{\prime}=\mathrm{T}_{3}{ }^{\prime}\left({ }^{\circ} \mathrm{C}\right)$

Step 3: Calculating the average temperature of the samples $T=\left(T_{d}+T_{c}\right) / 2$, determining $c_{n}, c_{n d}$, $\mathrm{c}_{\mathrm{ck}}$ with $\mathrm{T}$

Step 4: Calculating $\phi_{1}, \phi_{2}, \phi_{3}$, (Dzung et al., 2012)

Step 5: Substituting $\phi_{1}, \phi_{2}, \phi_{3}$ into the Eq. (13) to determine the relationship between the rate of freezing water inside Royal jelly sample and average temperature $T$. The results obtained were represented in Table 3, 4 and 5

Step 6: Substituting the experimental data in Table 3, 4 and 5 into the Eq. (14) will be determined the mathematical model about the relationship between the rate of freezing water and freezing temperature of Royal jelly.

\section{RESULTS AND DISCUSSION}

Determining the rate of freezing water of royal jelly by the mathematical model (13) and experiment: The physical properties of the copper box, water, ice and the composition of dry matter inside Royal jelly are used to calculate the rate of freezing water according to freezing temperature of Royal jelly (Heldman, 1982; Heldman et al., 1983), including:

- The physical properties of the copper box:

$$
\mathrm{G}_{1}=0.125 \mathrm{~kg} ; \mathrm{c}_{1}=380 \mathrm{~J} /(\mathrm{kg} . \mathrm{K})
$$

- The physical properties of the water (Heldman and Daryl, 1992):

When $0^{\circ} \mathrm{C}<\mathrm{T}<150^{\circ} \mathrm{C}$ :

$$
\begin{aligned}
& \mathrm{c}_{\mathrm{n}}=4167.2-9086.4 \times 10^{-5} \times \mathrm{T}+5473.1 \times 10^{-6} \times \mathrm{T}^{2} \\
& (\mathrm{~J} /(\mathrm{kg} . \mathrm{K}))
\end{aligned}
$$

When $-40^{\circ} \mathrm{C} \leq \mathrm{T} \leq 0^{\circ} \mathrm{C}$, (In spite of water inside food under $0^{\circ} \mathrm{C}$, it was still no crystallization):

$$
\begin{aligned}
& \mathrm{c}_{\mathrm{n}}=4080.7-5306.2 \times 10^{-3} \times \mathrm{T}+9951.6 \times 10^{-4} \times \mathrm{T}^{2}(\mathrm{~J} / \\
& (\mathrm{kg} . \mathrm{K}))
\end{aligned}
$$

- The physical properties of ice (the freezing water), (Heldman and Daryl, 1992):

$$
\begin{aligned}
& \mathrm{c}_{\text {nd }}=2062.3+6076.9 \times 10^{-3} \times \mathrm{T}(\mathrm{J} /(\mathrm{kg} . \mathrm{K})) ; \text { with } \\
& \mathrm{T} \leq 0^{\circ} \mathrm{C} \\
& \mathrm{L}=333601.5+1.054 \times \mathrm{T}-0.000021 \times \mathrm{T}^{2}(\mathrm{~J} / \mathrm{kg})
\end{aligned}
$$

Where the temperature $\mathrm{T}$ is taken to be the numerical value in ${ }^{\circ} \mathrm{C}$.

- The physical properties of the composition of dry matter inside Royal jelly (Heldman and Daryl, 1992):

Protein:

$$
\begin{aligned}
& \mathrm{c}_{\text {pro }}=2008.2+1208.9 \times 10^{-3} \mathrm{~T}+1312.9 \times 10^{-6} \times \mathrm{T}^{2}(\mathrm{~J} / \\
& (\mathrm{kg} . \mathrm{K}))
\end{aligned}
$$

Carbohydrate: 


$$
\begin{aligned}
& \mathrm{c}_{\text {glu }}=1548.8+1962.5 \times 10^{-3} \times \mathrm{T}+5939.9 \times 10^{-6} \times \mathrm{T}^{2} \\
& (\mathrm{~J} /(\mathrm{kg} . \mathrm{K}))
\end{aligned}
$$

Lipit:

$$
\begin{aligned}
& \mathrm{c}_{\text {lip }}=1984.2+1473.3 \times 10^{-3} \times \mathrm{T}+4800.8 \times 10^{-6} \times \mathrm{T}^{2}(\mathrm{~J} / \\
& (\mathrm{kg} . \mathrm{K}))
\end{aligned}
$$

Ash:

$$
\begin{aligned}
& \mathrm{c}_{\text {ash }}=1092.6+1889.6 \times 10^{-3} \times \mathrm{T}+3681.7 \times 10^{-6} \times \mathrm{T}^{2} \\
& (\mathrm{~J} /(\mathrm{kg} . \mathrm{K}))
\end{aligned}
$$

The average specific heat of impurities inside the dry matter of Royal jelly: $\mathrm{c}_{\mathrm{im}}=1296.87 \mathrm{~J} /$ (kg.K).

Dry matter:

$$
\begin{aligned}
& \mathrm{c}_{\mathrm{ck}}=\mathrm{X}^{\mathrm{tp}}{ }_{\text {pro }} \mathrm{c}_{\text {pro }}+\mathrm{X}^{\mathrm{t}} \mathrm{glu}_{\mathrm{glu}} \mathrm{c}_{\mathrm{glu}}+\mathrm{X}^{\mathrm{tp}}{ }_{\text {Lip }} \mathrm{c}_{\mathrm{Lip}}+\mathrm{X}^{\mathrm{tp}}{ }_{\text {ash }} \mathrm{c}_{\text {ash }}= \\
& \Sigma \mathrm{X}_{\mathrm{j}} \mathrm{c}_{\mathrm{j}}(\mathrm{J} /(\mathrm{kg} . \mathrm{K}))
\end{aligned}
$$

where, $\mathrm{X}^{\mathrm{tp}}{ }_{\text {pro }}=0.34951 ; \mathrm{X}_{\text {glu }}^{\mathrm{tp}}=0.39093 ; \mathrm{X}_{\text {Lip }}^{\mathrm{tp}}=$ $0.09804 ; \mathrm{X}^{\mathrm{tp}}$ ash $=0.02696 ; \mathrm{X}^{\mathrm{tp}}{ }_{\mathrm{im}}=0.13456$ were ratio of protein, sugars lipid, ash and impurities inside the composition of the dry matter of Royal jelly (the composition of impurities inside Royal jelly were cera flava, including: Myricyl palmitat, myricyl cerotatat, alcol myricylics, cerylic and some hydrocarbon); $\mathrm{G}=$ $0.158 \mathrm{~kg} ; \mathrm{W}_{\mathrm{a}}=0.5920 ; \varphi=0.1311$.

Experiments were carried out according to six steps as were presented method section. The results have determined $\mathrm{T}_{\mathrm{d}}, \mathrm{T}_{\mathrm{c}}, \phi_{1}, \phi_{2}, \phi_{3}, \mathrm{U}, \mathrm{I}$ and $\tau$ and $\omega_{\mathrm{E}}$ were presented in Table 3, 4 and 5.

From Table 3, 4, 5, substituting value of $\mathrm{T}_{\mathrm{d}}, \mathrm{T}_{\mathrm{c}}, \phi_{1}$, $\phi_{2}, \phi_{3}, \mathrm{U}, \mathrm{I}$ and $\tau$ into the Eq. (13) to determine the rate of freezing water with the freezing temperature of Royal jelly and were presented in Table 5 .

Determining the mathematical model about the relationship between the rate of freezing water and freezing temperature of royal jelly: The relationship between the rate of freezing water and freezing temperature of Royal jelly obey law of the Eq. (14), (Sbijov, 1967; Heldman and Daryl, 1992). The problem posed here is needed to determine parameters of mathematical model $b_{0}, b_{1}, b_{2}, b_{3}$ and $b_{4}$. The method determines these parameters as follows:

The residual Root Mean Square Error (RMSR) of the rate of freezing water in Royal jelly from the experimental data and the mathematical model was presented by Eq. (15), (Dzung, 2012):

$$
\begin{aligned}
& \operatorname{RMSR}=f\left(b_{0}, b_{1}, b_{2}, b_{3}, b_{4}\right) \\
& =\sqrt{\frac{1}{N-1} \sum_{i=1}^{N}\left(\omega_{E}\left(T_{i}\right)-\omega_{M}\left(T_{i}\right)\right)^{2}}
\end{aligned}
$$

where,
$\omega_{\mathrm{E}}\left(\mathrm{T}_{\mathrm{i}}\right)=$ The rate of freezing water inside Royal jelly at temperature of $\mathrm{T}_{\mathrm{i}}$ from experiment in Table 5

$\omega_{M}\left(T_{i}\right)=b_{0}+b_{1} \exp \left(b_{2}+b_{3} T_{i}+b_{4} T_{i}^{2}\right)$ : the rate of freezing water inside Royal jelly at temperature of $T_{i}$ from the mathematical model (14)

i $\quad=1 \div \mathrm{N}$ : the number of experiments

$\mathrm{T}_{\mathrm{i}} \quad=$ The average temperature of Royal jelly in Table 5

This much, the problem finding parameters $b_{0}, b_{1}$, $b_{2}, b_{3}$ and $b_{4}$ of mathematical model (14) was expressed as follow: Finding the root $b^{\text {opt }}=\left(b_{0}{ }^{\text {opt }}, b_{1}{ }^{\text {opt }}, b_{2}{ }^{\text {opt }}, b_{3}{ }^{\text {opt }}\right.$, $\left.\mathrm{b}_{4}{ }^{\text {opt }}\right)$ in order to objective function of RMSR $=\mathrm{f}\left(\mathrm{b}_{0}, \mathrm{~b}_{1}\right.$, $b_{2}, b_{3}, b_{4}$ ) reached the minimum value:

RMS $\mathrm{R}_{\min }=\operatorname{Min}\left\{\mathrm{f}\left(\mathrm{b}_{0}, \mathrm{~b}_{1}, \mathrm{~b}_{2}, \mathrm{~b}_{3}, \mathrm{~b}_{4}\right)\right\}=\mathrm{f}\left(\mathrm{b}_{0}{ }^{\mathrm{opt}}\right.$, $\mathrm{b}_{1}{ }^{\mathrm{opt}}, \mathrm{b}_{2}{ }^{\mathrm{opt}}, \mathrm{b}_{3}{ }^{\mathrm{opt}}, \mathrm{b}_{4}{ }^{\mathrm{opt}}$ )

$$
=\operatorname{Min}\left\{\sqrt{\frac{1}{N-1} \sum_{i=1}^{N}\left(\omega_{E}\left(T_{i}\right)-\omega_{M}\left(T_{i}\right)\right)^{2}}\right\}
$$

From the data in Table 5, the minimum value of RMSR could be determined by using the meshing method (Dzung, 2012) programmed in MATLAB 7.0 software. After solving and calculating, the root of Eq. (16) found the results as follows:

$$
\text { RMS } \mathrm{R}_{\min }=0.0052
$$

where,

$$
\begin{aligned}
& \mathrm{b}_{0}{ }^{\mathrm{opt}}=1.0000 ; \mathrm{b}_{1}{ }^{\mathrm{opt}}=-0.55009 ; \mathrm{b}_{2}{ }^{\mathrm{opt}}=0.59767 \\
& \mathrm{~b}_{3}{ }^{\text {opt }}=0.27390 ; \mathrm{b}_{4}{ }^{\text {opt }}=-0.01563
\end{aligned}
$$

Consequently, mathematical model describing the relationship between the rate of freezing water with freezing temperature of Royal jelly was established by mathematical model (13) and experimental method as follow:

$$
\begin{aligned}
& \omega_{\mathrm{M}}(\mathrm{T})=1-0.55009 \times \mathrm{e}^{0.59767+0.27390 \times \mathrm{T}-0.01563 \times \mathrm{T}^{2}} \\
& =1-0.55009 \times \operatorname{Exp}(0.59767+0.27390 \times \mathrm{T}- \\
& \left.0.01563 \times \mathrm{T}^{2}\right)
\end{aligned}
$$

Test compatibility of the mathematical model (17): Error of the mathematical model (17) with experimental data was examined by using the Eq. (18) as follows (Gebhart, 1992; Dzung, 2012):

$$
\operatorname{Er}=\frac{\left|\omega_{E}\left(T_{i}\right)-\omega_{M}\left(T_{i}\right)\right|}{\left|\omega_{E}\left(T_{i}\right)\right|}
$$




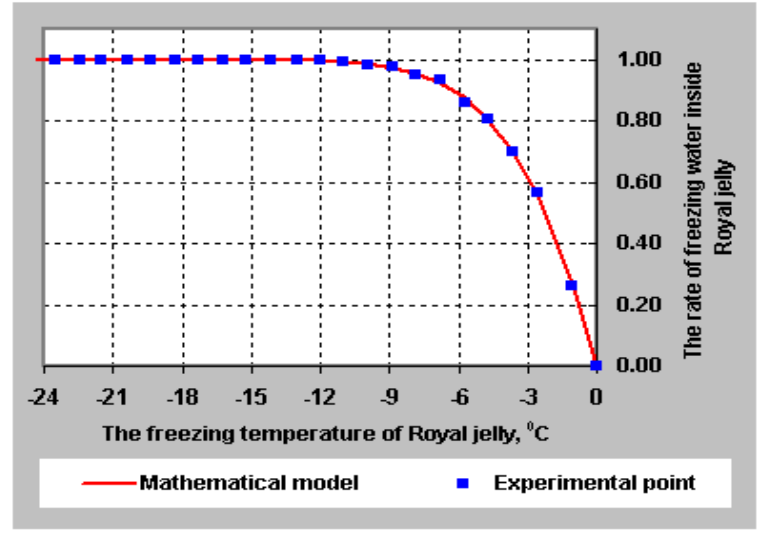

Fig. 5: Relationship between the rate of freezing water and freezing temperature of royal jelly

$$
\begin{aligned}
\operatorname{Er}_{\max }=\frac{\max }{\left\{\left|\omega_{E}\left(T_{i}\right)-\omega_{M}\left(T_{i}\right)\right|\right\}} & \left|\omega_{E}\left(T_{i}\right)\right| \\
= & \frac{|0.2609-0.2718|}{0.2609} \cdot 100 \%=4.16 \%
\end{aligned}
$$

It was able to see that the mathematical model (17) was completely compatible with experimental results.

Because of the maximum error of mathematical model (17) with experimental data $\mathrm{Er}_{\max }=4.16 \%$, it is smaller than 5\% (Heldman and Daryl, 1992; Dzung et al., 2012).

Therefore, the mathematical model (17) can completely use of calculating mass and energy balance in the freezing process (Holman, 1986).

In Fig. 5 described the rate of freezing water to vary according to temperature of Royal jelly in freezing process. When the freezing temperature of Royal jelly reduced, the rate of freezing water of freezing Royal jelly increased. At the time, the rate of freezing water of freezing Royal jelly was $\omega=1$, if the freezing process continue to reduce the temperature of freezing Royal jelly, the rate of freezing water of freezing Royal jelly will be still constant and $\omega=1$.

Determining the optimal freezing temperature of royal jelly: At the time, water inside Royal jelly begin to be crystallized over $0.86(86 \%)$, the temperature of freezing Royal jelly will be the optimal freezing temperature of Royal jelly for using preservation. At the time, water inside Royal jelly begin to be completely crystallized $(\omega=1$, or $100 \%)$, the temperature of freezing Royal jelly will be the optimal freezing temperature of Royal jelly for using freeze drying. As a consequence of Table 5 and the mathematical model (17) building from experimental data determined the optimal freezing temperature of Royal jelly as follows:
- If the freezing process use of preservation, the optimal freezing temperature of Royal jelly will be $\mathrm{T}_{\text {Fopt }}=-5.73^{\circ} \mathrm{C}$, corresponding to $\omega=0.8602$ or $86.02 \%$, over $86 \%$.

- If the freezing process use of freeze drying, the optimal freezing temperature of Royal jelly will be $\mathrm{T}_{\mathrm{Fopt}}=-18.33^{\circ} \mathrm{C}$, corresponding to $\omega=1.0000$ or $100 \%$ and water inside Royal jelly will be completely crystallized.

It was obvious that the problem to determine rate of freezing water inside freezing material has been difficult and complicated question. Currently, this problem has still not had experimental method to determine. For this reason, this study shown that building the experimental method and mathematical model (13) to determine the rate of freezing water was a practical technological solution for food processing factories and was the basic foundation of science for research into freezing field.

The mathematical model (17) was established by experimental data in Table 3,4 and 5. It described rather suitable for relationship between the rate of freezing water and the freezing temperature of Royal jelly. Because testing compatibility of the mathematical model (17) shown that the maximum error of mathematical model (17) with experimental data was 4.16\%, under 5\% (Heldman and Daryl, 1992).

The mathematical model (13) and (17) were not only used to set up parameters for the operation of the freezing system and the freeze drying system but also to determine technological mode in freezing process and freeze drying of Royal jelly which grown in Vietnam.

Currently, freezing food processing factories often reduce the freezing temperature of freezing food to $(-18$ $\div-16$ ) ${ }^{\circ} \mathrm{C}$ for using in preservation. In such low temperature, microorganisms test showed that microorganisms could not grow, reproduce and most of the microorganisms are inactivated. However, the optimal freezing temperature of freezing food has not exactly determined yet. Results of This study were not only suitable to large-scale process but also a technological solution for factories to improve the freezing process, saving energy costs when the freezing system is operated (Dzung, 2007, 2012).

\section{NOMENCLATURE}

$\omega \in[0,1] \quad:$ The rate of freezing water

$\omega_{\mathrm{E}} \quad:$ The rate of freezing water determined by experimental method

$\omega_{\mathrm{M}} \quad$ : The rate of freezing water determined by mathematical model

$\mathrm{W}_{\mathrm{a}} \quad$ : Initial moisture of Royal jelly

$\mathrm{c}_{\mathrm{n}}, \mathrm{c}_{\mathrm{nd}}(\mathrm{J} / \mathrm{kg} . \mathrm{K})$ : Specific heat of water

$\mathrm{c}_{\mathrm{nd}}(\mathrm{J} /(\mathrm{kg} . \mathrm{K}) \quad$ : Specific heat of ice

$\mathrm{c}_{\mathrm{ck}}(\mathrm{J} /(\mathrm{kg} . \mathrm{K}))$ : Specific heat of the dry matter inside Royal jelly 
$\mathrm{c}_{1}(\mathrm{~J} /(\mathrm{kg} . \mathrm{K})) \quad$ : Specific heat of copper

$\mathrm{G}(\mathrm{kg}) \quad$ : Weight of Royal jelly sample

$\mathrm{G}_{1}(\mathrm{~kg}) \quad$ : Weight of copper box in equipment determine rate of freezing water in

Fig. 3

$\mathrm{T}_{\mathrm{cr}}=\mathrm{T}_{\mathrm{Fp}}\left({ }^{\circ} \mathrm{C}\right)$ : The freezing temperature of water inside Royal jelly

$\mathrm{T}_{\mathrm{SF}}\left({ }^{\circ} \mathrm{C}\right) \quad$ : The super freezing temperature

$\mathrm{T}_{\mathrm{R}}\left({ }^{\circ} \mathrm{C}\right) \quad$ : The room temperature

$\mathrm{T}_{\text {Fopt }}\left({ }^{\circ} \mathrm{C}\right) \quad$ : The optimal freezing temperature of Royal jelly (when water was crystillized over 86 or $100 \%$ )

$\mathrm{T}_{\mathrm{d}}=\mathrm{T}_{1}=\mathrm{T}_{2}=\mathrm{T}_{3}\left({ }^{\circ} \mathrm{C}\right)$ : Initial temperature of Royal jelly sample

$\mathrm{T}_{\mathrm{c}}=\mathrm{T}_{1}{ }^{\prime}=\mathrm{T}_{2}{ }^{\prime}=\mathrm{T}_{3}{ }^{\prime}\left({ }^{\circ} \mathrm{C}\right)$ : The temperature of Royal jelly sample after supplying energy

$\mathrm{T}=\left(\mathrm{T}_{\mathrm{d}}+\mathrm{T}_{\mathrm{c}}\right) / 2\left({ }^{\circ} \mathrm{C}\right):$ The average temperature of Royal jelly samples

$r_{n c}=L(J / k g) \quad:$ Latent heat of freezing water or lantent heat of thawing ice

$\mathrm{U}(\mathrm{V}) \quad$ : Number of Voltmeter

I (A) : Number of Amperemeter

$\mathrm{X}^{\mathrm{tp}}{ }_{\mathrm{pro}}, \mathrm{X}^{\mathrm{tp}}{ }_{\text {glu }}, \mathrm{X}_{\text {Lip }}^{\mathrm{tp}}, \mathrm{X}^{\mathrm{tp}}{ }_{\text {ash }}$ and $\mathrm{X}^{\mathrm{tp}}{ }_{\text {im }}$ : Ratio of protein, carbohydrate, lipid, ash and impurities inside the composition of the dry matter of Royal jelly

$\tau(\mathrm{s}) \quad:$ Heat supply time

$\varphi=0.1311(13.11 \%):$ The loss of heat coefficient

RMSR : The residual Root Mean Square Error

\section{CONCLUSION}

The new method and the mathematical model (13) was built to determine the rate of freezing water according to the freezing temperature of Royal jelly by the energy balance equation of the warming up and thawing process of freezing Royal jelly. This method was the basic foundation of science for research into freezing field.

From the experimental data in Table 3, 4 and 5 has established the mathematical model (17) which was completely compatible with experiment. The results obtained also determined the optimal freezing temperature of Royal jelly. For the freezing process of Royal jelly was used in preservation, the optimal freezing temperature of Royal jelly would reached maximum value of $-5.73^{\circ} \mathrm{C}$. For the freezing process of Royal jelly was used in freeze drying, the optimal freezing temperature of Royal jelly would reached maximum value of $-18.33^{\circ} \mathrm{C}$. On that foundation will build and solve the optimization multi-objective problem to describe the freezing process, simultaneous determine the technological mode of the freezing process.
This much, the mathematical model (17) can be completely used to calculate and determine the technological mode for the freezing process of Royal jelly in Vietnam.

\section{ACKNOWLEDGMENT}

The author thanks Department of Food Technology and Faculty of Chemical and Food Technology, HCMC University of Technical Education, Viet Nam, for help with experiments carrying out.

\section{REFERENCES}

Antinelli, J.F., Z. Sarah, D. Renée, R. Catherine, F. Jean-Paul and L. Louisette, 2003. Evaluation of (E)-10-hydroxydec-2- enoic acid as a freshness parameter for royal jelly. Food Chem., 80: 85-89.

Benfenati, et al., 1986. Book "Value-Added Products from Beekeeping. Chapter 6: Royal Jelly", FAO. www.fao.org/docrep/w00 76e/w0076e16.htm.

Bon, P.V. and N.D. Tho, 2002. Heat Transfer Process and Heat Transfer Equipment. 3rd Edn., Published by VNU HCMC, Viet Nam, pp: 56-120.

Cleland, A.C. and R.L. Earle, 1979. Pridiction of freezing times for foods in rectangular packages. J. Food Sci., 44: 964.

Dzung, N.T., 2007. Technilogical Freezing Food. 2nd Edn., Published by VNU HCMC, Viet Nam, (Chapter 1,2).

Dzung, N.T., 2012a. Optimization the freezing process of penaeus monodon to determine technological mode of freezing for using in the freeze drying. Canadian J. Chem. Eng. Technol., 3(3): 45-53.

Dzung, N.T., V.D. Trinh and D.B. Tran, 2012b. Building the method to determine the rate of freezing water of penaeus monodon. Adv. J. Food Sci. Technol., 4(5).

Figura, L.O. and A.T. Arthur, 2007. Food Physics: Physical Properties Measurement and Application. Springer-Verlag Berlin Heidelberg, Berlin, London, pp: 550, ISBN: 3540341943.

Gebhart, B., 1992. Heat Conduction and Mass Diffusion. 1st Edn., McGraw - Hill, New York, pp: 78-98.

Golovkin, K.K., 1972. Parametric Normed Spaces and Normed Massives. American Mathematical Soc., Providence, pp: 121, ISBN: 0821830066.

Hattori, N., H. Nomoto, H. Fukumitsu, S. Mishima and S. Furukawa, 2007. Royal jelly and its unique fatty acid, 10-hydroxy-trans-2-decenoic acid, promote neurogenesis by neural stem/progenitor cells in vitro. Biomed. Res. (Tokyo, Japan), 28(5): 261-266.

Heist, J.A., 1979. Freeze crystallization. Chem. Eng., 86(10): 72. 
Heldman, D.R., 1982. Food properties during freezing. Food Technol., 36(2), p 92-109.

Heldman, D.R., et al., 1983. Thermal Properties of Frozen Foods. In: Martin, R.O. (Ed.), Physical and Chemical Properties of Foods. ASAE, St. Joseph, Minnesota, pp: 120-137.

Heldman, D.R. and B.L. Daryl, 1992. Handbook of Food Engineering. 2nd Edn., Marcel Dekker New York, Basel, Hong Kong, pp: 247-388.

Holman, J., 1986. Heat Transfer. 1st Edn., McGraw Hill, New York, pp: 167-197.

Jean, M.B., et al., 1996. Thermodynamics. Hachette Supérieur, pp: 319.

Lercker, G., M.A. Vecchi, A.G. Sabatini and A. Nanetti, 1984. Controllo chimico analitico della gelatina reale. Riv. Merceol., 23(1): 83-94.
Lercker, G., M.F. Caboni, M.A. Vecchi, A.G. Sabatini and A. Nanetti, 1992. Caratterizzazione Dei Principali Costituenti Della Gelatina Reale. Apicoltura, 8.

Luikov, A., 1974. Conjugate convective heat transfer problems. Int. J. Heat Mass Transfer., 17: 257-267.

Raoult, J., 1958. Clinical measurement of resistance to flow of aqueous humor. Arch. Ophtalmol. Rev. Gen. Ophtalmol., 18(6): 657-661.

Sbijov, G.B., et al., 1967. Book "Heat Transfer and Freezing Food. (Translator: Bon P.V)", 3rd Edn., Published by VNU HCMC, Viet Nam, pp: 56-120.

Schmidt and Buchmann, 1992. Book "Value-Added Products from Beekeeping. Chapter 6: Royal jelly, FAO, Retrieved from: www.fao.org/docrep/w00 76e/w0076e16.htm. 